\title{
34. DISTRIBUTION OF BENTHONIC FORAMINIFERA IN UPPER JURASSIC AND LOWER CRETACEOUS DEPOSITS AT SITE 261, DSDP LEG 27, IN THE EASTERN INDIAN OCEAN
}

\author{
K. I. Kuznetsova, Geological Institute of the USSR Academy of Sciences, Moscow
}

Benthonic foraminifera from 18 samples selected from Site 261 (Figure 1) were studied in order to determine their age and stratigraphic range. The samples, which were selected by V. A. Krasheninnikov, were washed and treated during the leg; the microfauna was selected at the Geological Institute of the Academy of Sciences of the USSR in Moscow.

The following samples have been studied at Site 261: 29 , CC; 30-2, 7-9 cm; 30-4,44-46 cm;30-3, 63-64 cm; 30, CC; $31-3,10-12 \mathrm{~cm} ; 31-2,22-23 \mathrm{~cm} ; 31-4,32-34 \mathrm{~cm} ; 31-5$, $60-62 \mathrm{~cm} ; 31, \mathrm{CC} ; 32-4,40-42 \mathrm{~cm} ; 32-2,59-60 \mathrm{~cm} ; 32-3$, $83-85 \mathrm{~cm} ; 32$, CC; 33 , CC; $35-5,120-122 \mathrm{~cm} ; 35-5,128-$ $130 \mathrm{~cm}$; and $35, \mathrm{CC}$.

All of the samples studied contain foraminifera, together with radiolarians, ostracods, sponge spicules, and, in one sample (Sample 30, CC), fish scales.

The foraminiferal assemblages are characterized by the following features:

1) All the foraminifera are benthonic. Agglutinated forms are predominant and some assemblages consist entirely of these forms (Samples 31-2, 22-23 cm; 30-2, 7$9 \mathrm{~cm}$ ).

2) Some assemblages contain many species and numerous specimens (Samples 32, CC; 32-3, 83-85 cm; $32-4,40-42 \mathrm{~cm}$; etc.). Others contain few species represented by only sporadic specimens (Samples 35-5, 120$122 \mathrm{~cm} ; 32-2,59-60 \mathrm{~cm} ; 31-4,32-34 \mathrm{~cm} ; 29, \mathrm{CC})$.

3) Most of the benthonic foraminifera are well preserved. Agglutinated foraminifera as a rule are better preserved than calcareous ones.

4) The foraminifera from Site 261 exhibit considerable diversity with over 90 species present. These have been attributed to 44 genera from 12 families.

The systematic composition of the foraminiferal fauna is as follows:

Family Astrorhizidae (Rhizammina, Hyperammina, Hippocrepina, Saccorhiza)

Family Saccamminidae (Pelosina, Sorosphaera)

Family Ammodiscidae (Ammovertella, Ammolagena, Lituotuba, Glomospira, Glomospirella)

Family Hormosinidae (Reophax)

Family Lituolidae (Haplophragmoides, Ammobaculites, Haplophragmium, Placopsilina)

Family Textulariidae (Textularia, Bigenerina)

Family Trochamminidae (Trochammina)

Family Ataxophragmiidae (Verneuilinoides, Dorothia)

Family Nodosariidae (Lenticulina, Planularia, Marginulina, Vaginulina, Frondicularia, Falsopalmula, Dentalina, Nodosaria, Bojarkaella, Lingulina, Lagena, Pseudonodosaria)

Family Polymorphinidae (Pyrulina, Ramulina)

Family Ceratobuliminidae (Epistomina?)

Family Spirillinidae (Spirillina)

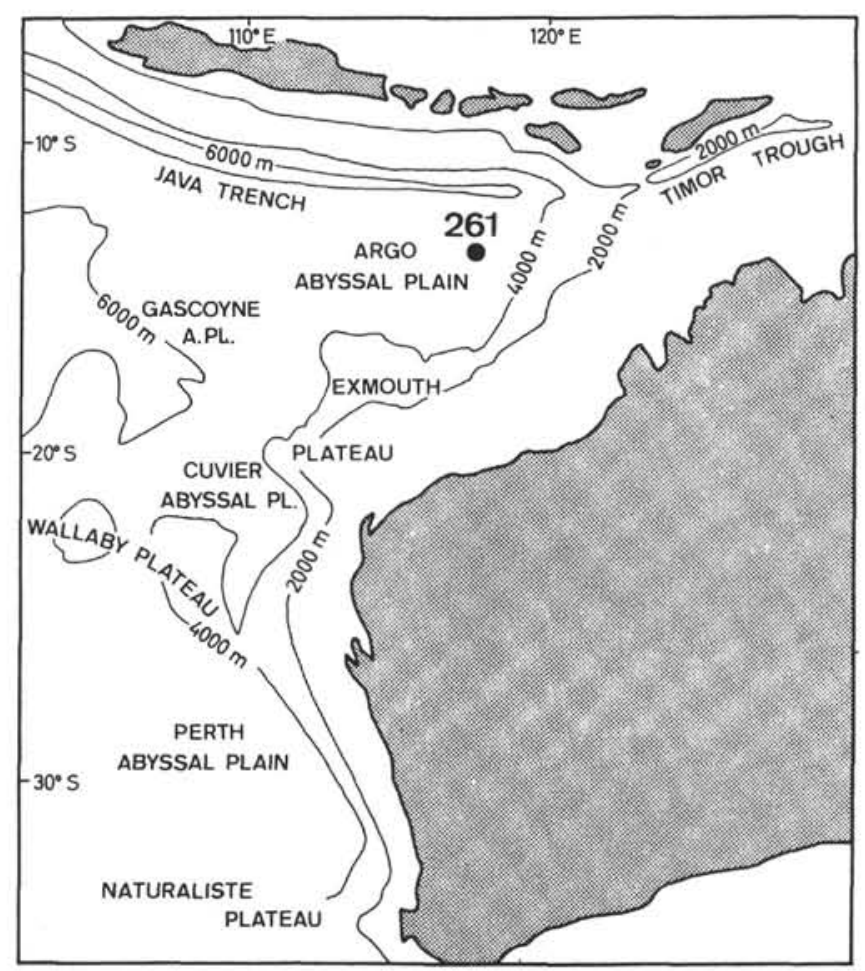

Figure 1. Location of Leg 27, Site 261.

The relative proportions of the different foraminiferal families in two different stratigraphic horizons are given in Figure 2.

Despite the considerable diversity in faunal composition and the high degree of fossil preservation, it is difficult to use the fauna for a stratigraphic subdivision of the section. This is primarily due to the absence of index species necessary for precise age assignments of individual parts of the section. In addition, in the lower half of the sequence at Site 261 (Samples 35, CC and 32$4,40-42 \mathrm{~cm}$ ), there is a mixed assemblage containing abundant Cretaceous forms as well as some Late Jurassic elements, such as Lenticulina quenstedti (Guebel), L. subtilis (Wisniowski), Ramulina spandeli Paalzov, etc. The Jurassic species are represented by sparse specimens and probably represent reworked older material. The absence of Jurassic elements characteristic for the Callovian and Oxfordian, such as Ophthalamidiidae, Ceratobuliminidae, and Trocholina, is particularly suggestive of a Cretaceous age. However, this part of the section also contains nannoplankton, such as Stephanolition bigoti, whose stratigraphic range is limited to the Callovian and Oxfordian. Based on these data, the section from Sample 35, CC to Sample 

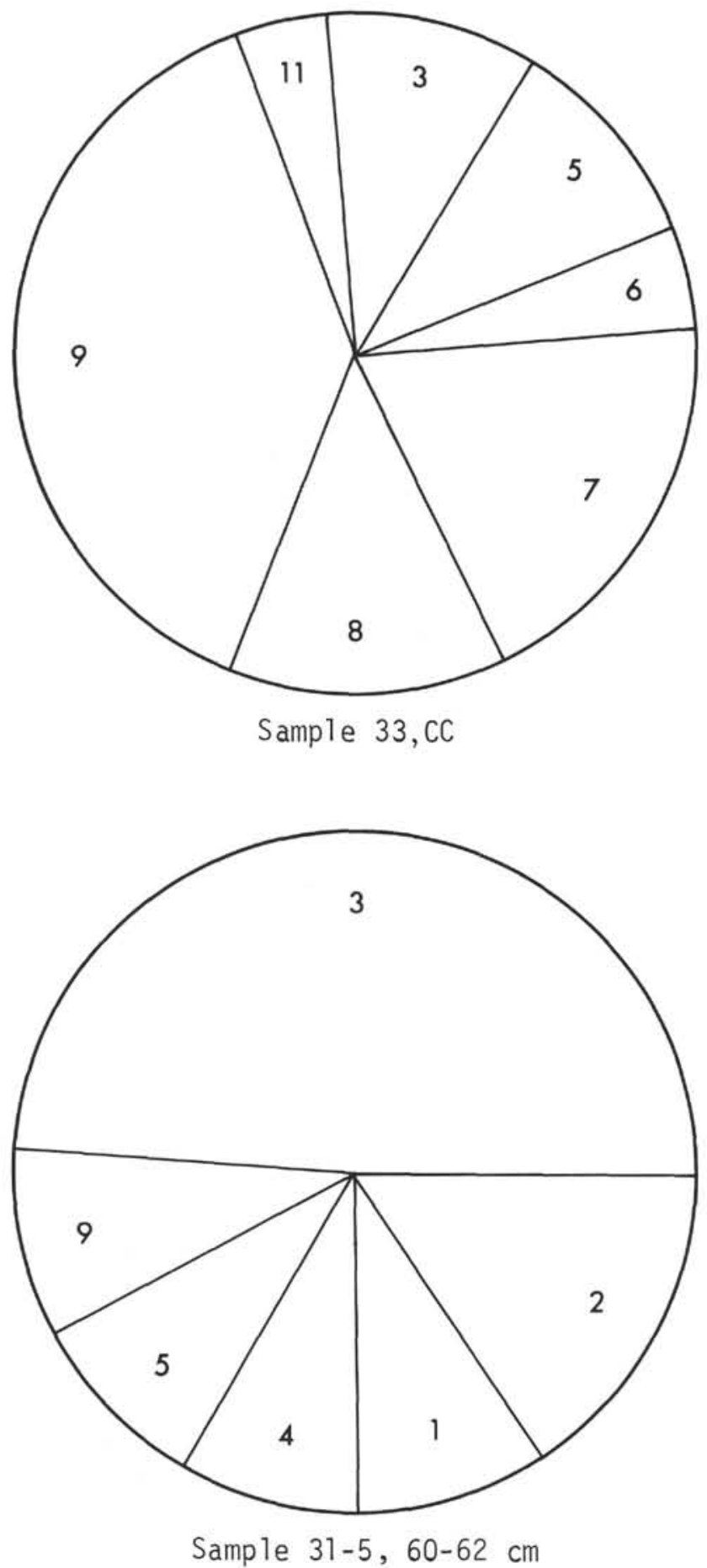

Figure 2. Relative proportions of families of foraminifera in various stratigraphic horizons at Site 261: (1) Astrorhizidae; (2) Saccamminidae; (3) Ammodiscidae; (4) Hormosinidae; (5) Lituolidae; (6) Textulariidae; (7) Trochamminidae; (8) Ataxophragmiidae; (9) Nodosariidae; (11) Spirillinidae.

$32-4,40-42 \mathrm{~cm}$ is provisionally assigned an Upper Jurassic-Lower Cretaceous age. It should be emphasized that this age assignment does not imply a transitional age (uppermost Tithonian to lowermost Berria- sian) but merely a degree of uncertainty due to mixing of Jurassic (Oxfordian to Callovian) and Cretaceous (probably not older than Valanginian) elements.

Beginning from Sample 31, CC, but mostly in Samples 30, CC and 30-4, 44-46 cm, almost only Valanginian species, su $\mathrm{h}$ as Haplophragmium inconstans inconstans Bartenstein and Brand, Trochammina inflata (Montagu), Verneulinoides neocomensis (Mjatliuk), Dorothia subtrochus (Bartenstein), and Lenticulina aff. oligostegia (Reuss) are present. Many of these species have a wide stratigraphic range and are therefore not suitable for dating the sediments. The assemblage as a whole, however, indicates that this part of the section is Valanginian in age (see Table 1). This age assignment is supported by other workers (M. Moullade, T. Gorbachik, and V. A. Basov) who have examined these faunas. These specialists also agree that the older assemblages in Sample 35, CC to Sample 31, $\mathrm{CC}$ are Lower Cretaceous, with the Jurassic elements being reworked from older material.

Successive and pronounced changes in the foraminiferal fauna that would allow for a more detailed stratigraphic subdivision of the section have not been recognized. Nevertheless, the fauna reflects a gradual deepening of the basin with time. This is substantiated by a gradual decrease of calcareous elements in the faunal assemblages, accompanied by an increase in the number and systematic variety of agglutinated forms. Beginning from Sample 30, CC up, the calcareous foraminifera become very rare and are represented only by sporadic Nodosariidae (Lenticulina, Astacolus, Lagena). Based on the virtual absence of foraminifera with calcite tests in this part of the section, it is assumed that the sediments were deposited below the lysocline.

The upward increase in arenaceous foraminifera also probably reflects a decrease in water temperature. This conclusion is supported by comparison of foraminiferal assemblages at Site 261 with those from the Berriasian and Valanginian of North Siberia and the Arctic Islands (Basov and Ivanova, 1972; Scharovskaja, 1968). North Siberian assemblages of foraminifera in the Berriasian, and to a certain extent in the Valanginian, reflect a sublittoral environment as shown by the presence of abundant agglutinated forms of the families Ammodiscidae, Hyperamminidae, Saccamminidae, Lituolidae, Trochamminidae, and Ataxophragmiidae. The transition from the Berriasian to the Valanginian was characterized by a general reduction in specific composition of the foraminiferal assemblages.

The Valanginian assemblages of Sample $30, \mathrm{CC}$ to Sample 30-2, 7-9 cm also resemble, in their generic composition, Lower Cretaceous (Berriasian and Valanginian) assemblages from flysch deposits of the Crimea and the Carpathians (Gorbachik, 1969; MikhailovaIovcheva et al., 1965), but differ from them in the scarceness of total absence of calcareous specimens. Gorbachik points out that the beginning of the Valanginian is characterized in the Crimea by an increase in species, particularly of representatives of the family Nodosariidae.

Comparison of the Site 261 assemblages with foraminifera from the Valanginian stratotype in Switzerland is 
TABLE 1

Distribution of Foraminifera in Upper Jurassic-Lower Cretaceous Deposits at Site 261.

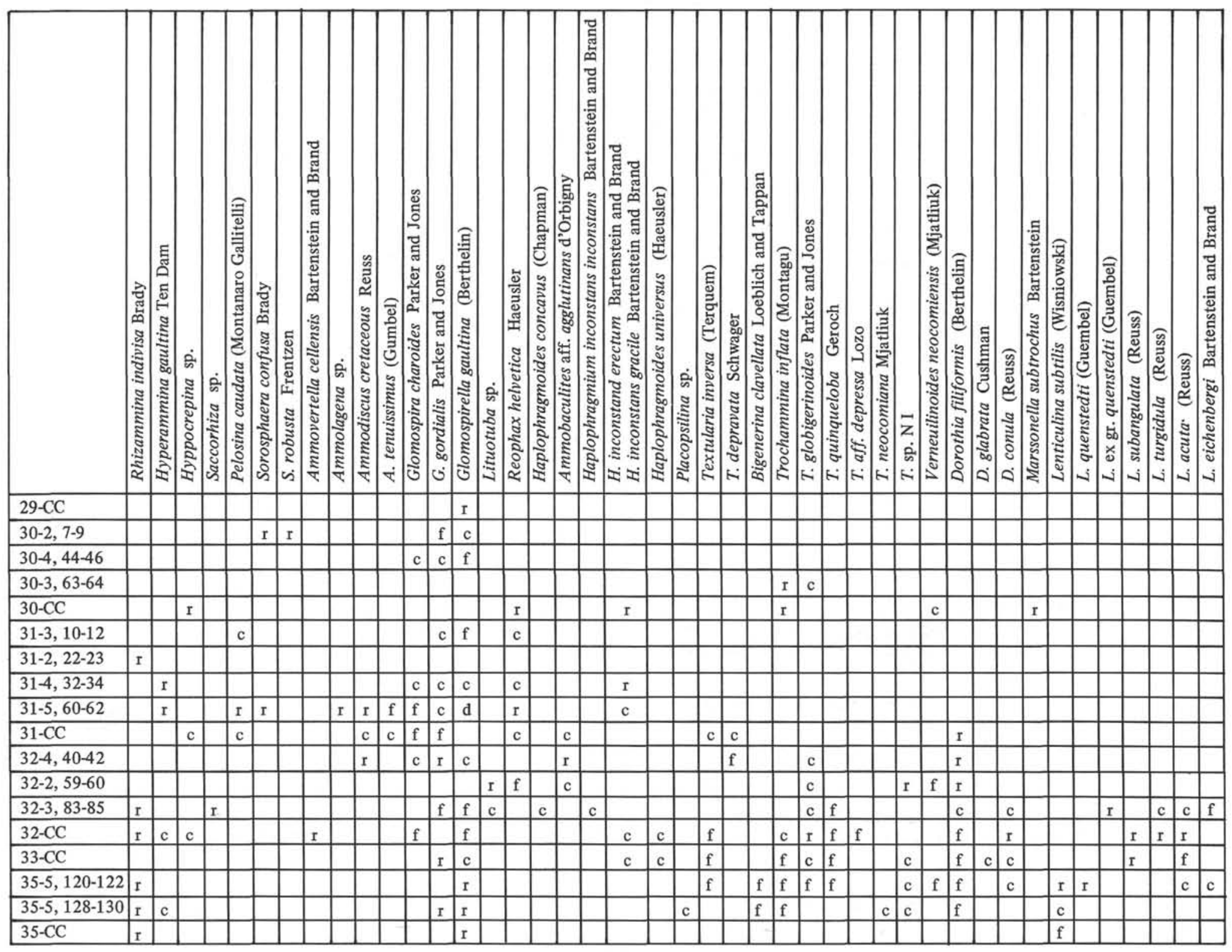


TABLE 1 - Continued

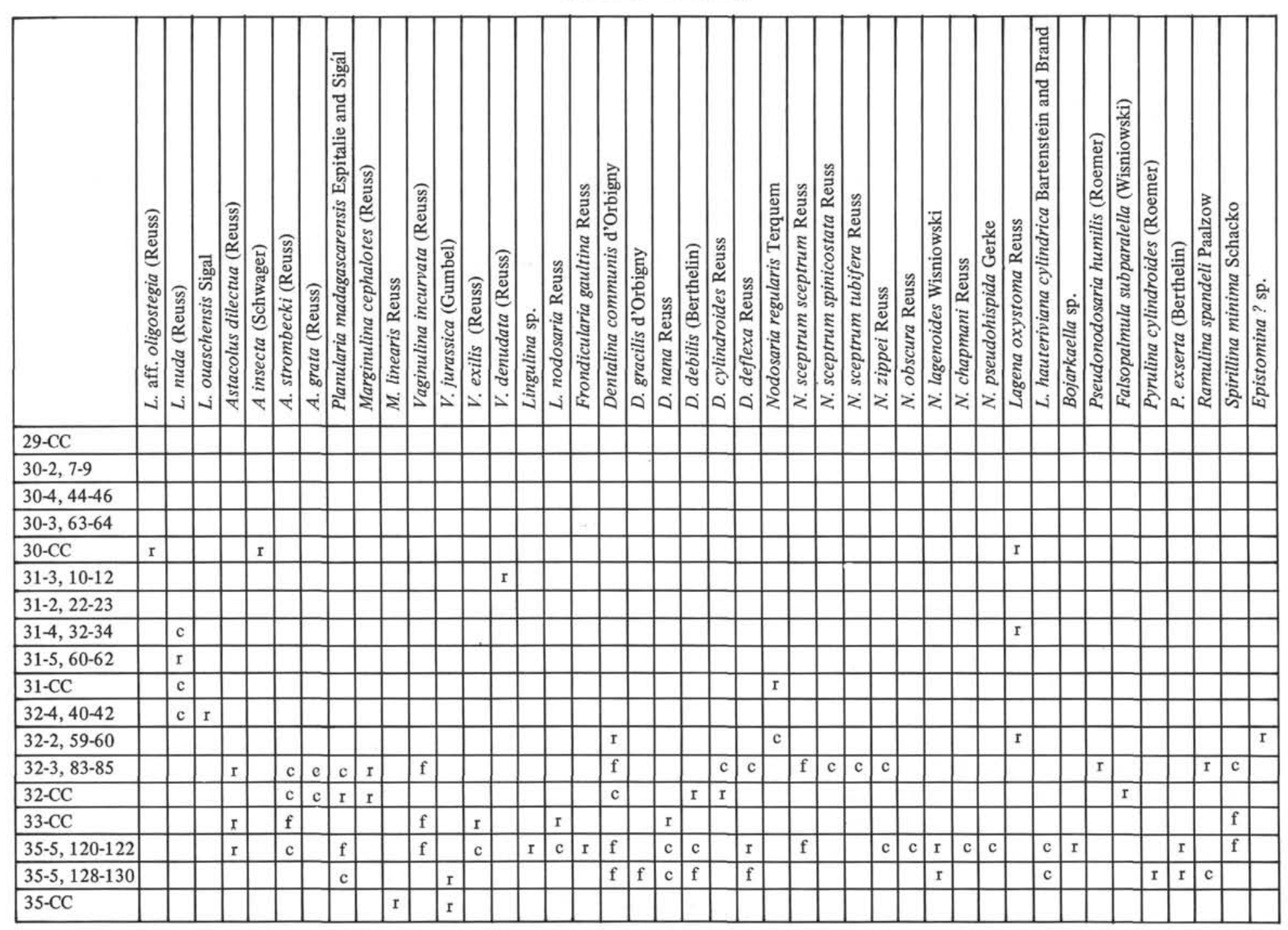


not possible because the type section consists of compact limestone whose foraminifera have not yet been studied.

So far, no directly comparable foraminiferal assemblages have been described from either the Indian Ocean or from more remote areas such as Europe, America, or North Africa.

\section{REFERENCES}

Basov, V. A. and Ivanova, E. F., 1972. Foraminifera. In The Jurassic-Cretaceous boundary and Berriasian stage in the boreal realm: "Nauka" Novosibirsk (in Russian).
Gorbachik, T. N., 1969. The peculiarity of distribution of foraminifera in Berriasian and Valanginian deposits in the Crimea: Vestnik Moscow Univers. N 6 (in Russian).

Mikhailova-Iovcheva, P., Zankov, V., Zaneva, P., Vaptsarova, J., Dikova, P., Trifonova, E., Budurov, K., and Bainova, E., 1965. The microfossil assemblages in Bulgaria: Sofia.

Scharovskaja, N. V., 1968. Assemblages of foraminifera from the Jurassic and Lower Cretaceous deposits of the UstEniseisky and Turuhan-Ermakovsky regions. Uchen. Zapiski NJJGA, paleontol. Stratigraphi: v. 23. (in Russian). 
PLATE 1

(All magnifications $\times 100$.)

Figure 1a, b Recurvoides sp.; a-lateral view; b-peripheral view; Sample 261-32, CC; Upper Jurassic-Lower Cretaceous (?).

Figure 2a, b Glomospirella gaultina (Berthelin); a-lateral view; b-peripheral view; Sample 261-30-4, 44-46 cm; Lower Cretaceous (Valanginian).

Figure 3a, b Trochammina globigeriniformis Parker and Jones; a, b-lateral view; Sample 261-32, CC; Upper Jurassic-Lower Cretaceous (?).

Figure 4a, b, c Trochammina inflata (Montagu); a-dorsal view; b-ventral view; c-peripheral view; Sample 26132-3, 83-85 cm; Upper Jurassic-Lower Cretaceous (?).

Figure 5a, b, c Trochammina quinqueloba Geroch; a-dorsal view; b-ventral view; c-peripheral view; Sample 261-32, CC; Upper Jurassic-Lower Cretaceous (?).

Figure 6a, b, c Verneuilinoides neocomiensis (Mjatliuk); a, b-lateral view; c-apertural view; Sample 261-32, CC; Upper Jurassic-Lower Cretaceous (?).

Figure 7a, b, c Trochammina sp. a-dorsal view; b-ventral view; c-peripheral view; Sample 261-32, CC; Upper Jurassic-Lower Cretaceous (?).

Figure 8a, b, c Textularia inversa (Terquem) a-lateral view; b-peripheral view; c-apertural view; Sample 261-32-33, 83-85 cm; Upper Jurassic-Lower Cretaceous (?).

Figure 9a, b Textularia depravata Schwager; a-lateral view; b-peripheral view; Sample 261-32, CC; Upper Jurassic-Lower Cretaceous (?).

Figure 10a, b Haplophragmium inconstans inconstans Bartenstein and Brand; a-lateral view; b-apertural view; Sample 261-30-4, 44-46 cm; Lower Cretaceous (Valanginian).

Figure 11a, b, c Dorothia conula (Reuss); a-lateral view; b-view from initial side; $\mathrm{c}$-view from apertural side.

Figure 12a Haplophragmium inconstans gracilis Bartenstein and Brand; a-lateral view; Sample 261-32, CC; Upper Jurassic-Lower Cretaceous (?).

Figure 13a, b Dorothia subtrochus (Bartenstein); a-view from the lateral side; b-view from the apertural side; Sample 261-30-4, 44-46 cm; Lower Cretaceous (Valanginian). 
PLATE 1
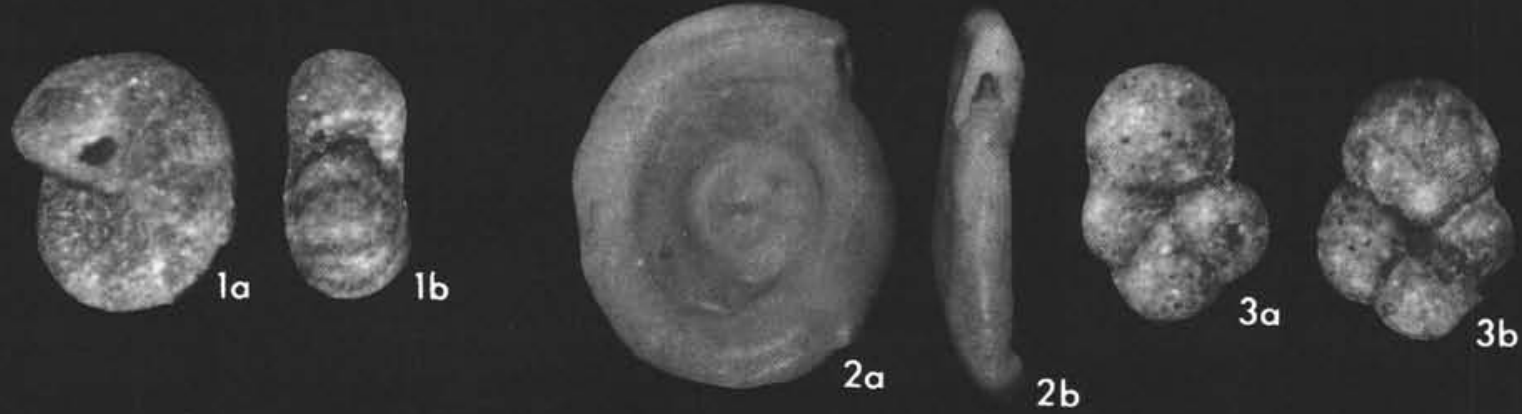

$2 b$
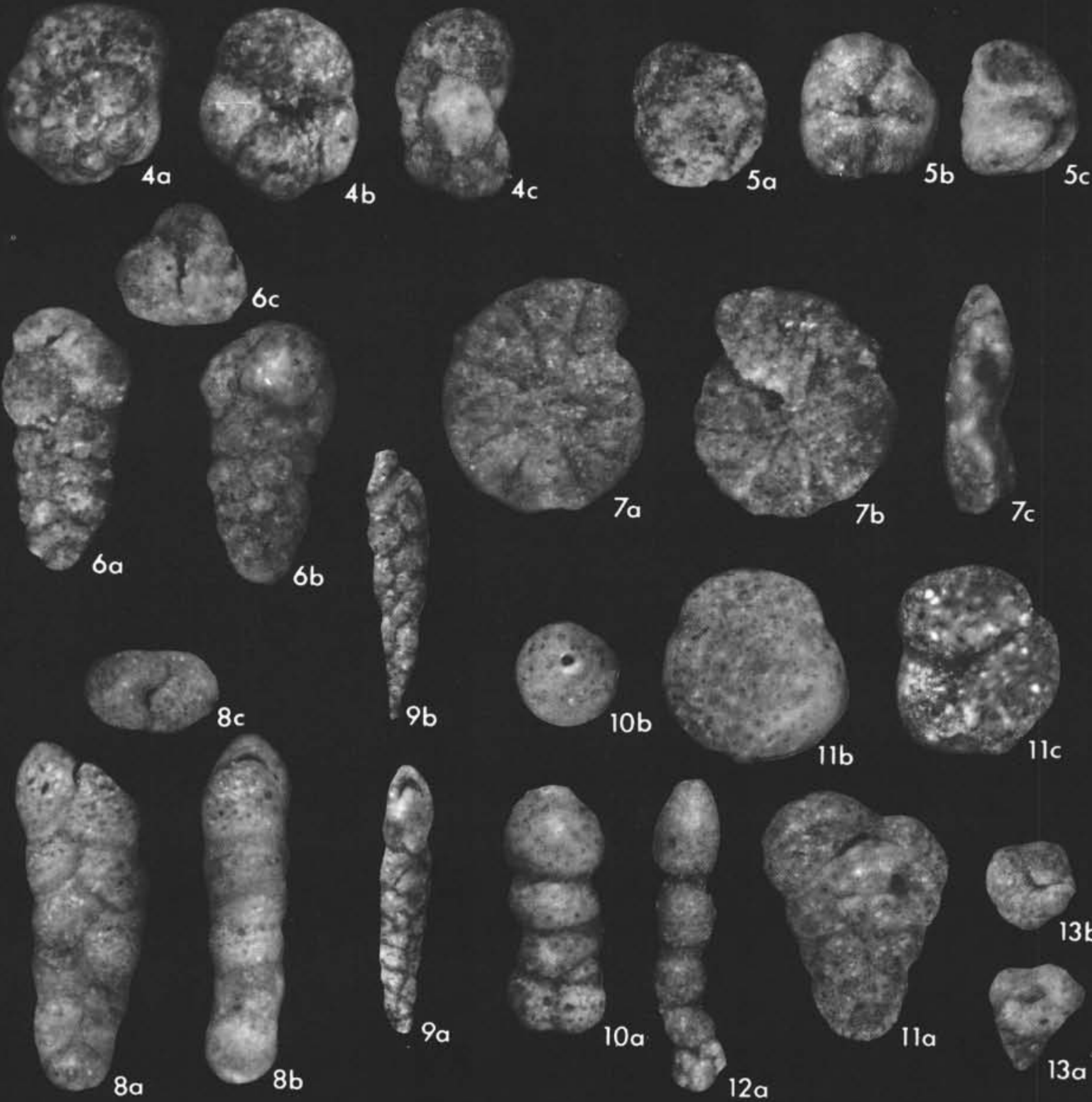

$6 b$
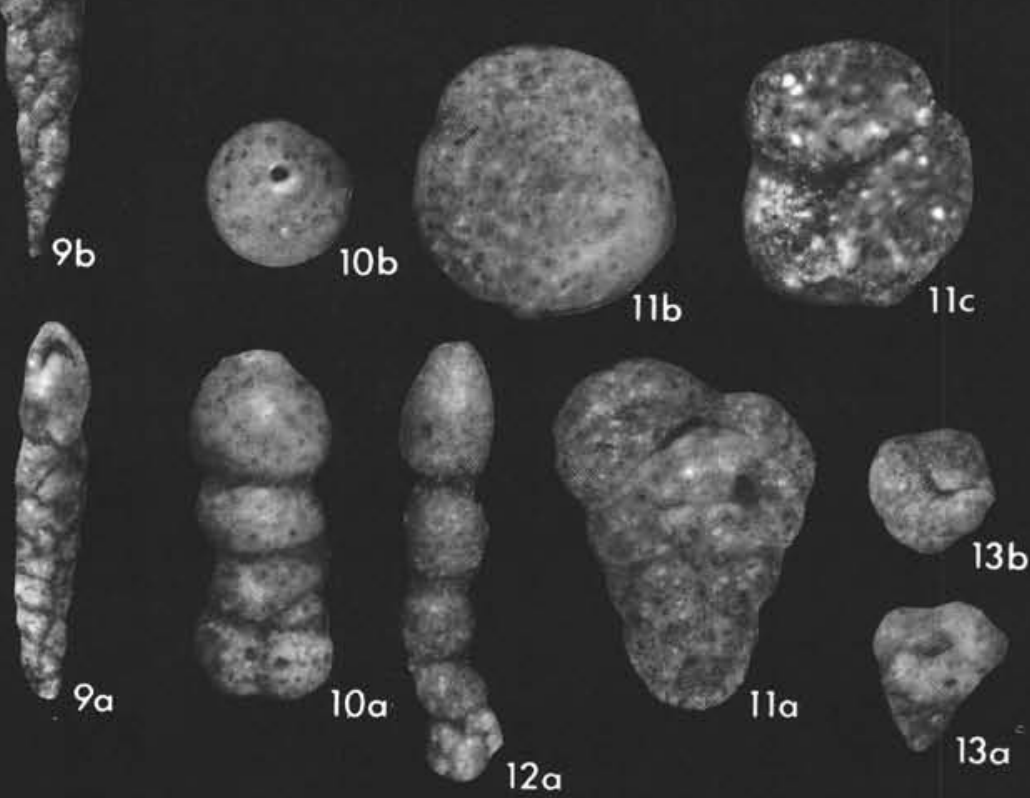
PLATE 2

(All magnifications $\times 100$.

a-lateral view; b-peripheral view; c-apertural view.)

Figure 1a,b Lenticulina ex gr. quenstedti (Gumbel); Sample 261-33, CC; Upper Jurassic-Lower Cretaceous.

Figure 2a, b Astacolus insectu (Schwager); Sample 261-30-4, 44$46 \mathrm{~cm}$; Lower Cretaceous (Valanginian).

Figure 3a, b Planularia madagascarensis Espitalié and Sigal; Sample 261-32, CC; Upper Jurassic-Lower Cretaceous (?).

Figure 4a, b Astacolus dilectus (Reuss); Sample 261-32, CC; Upper Jurassic-Lower Cretaceous (?).

Figure 5a, b Vaginulina demudata (Reuss); Sample 261-30-3, 63$64 \mathrm{~cm}$; Lower Cretaceous (Valanginian).

Figure 6a, b Vaginulina incurvata (Reuss); Sample 261-32, CC; Upper Jurassic-Lower Cretaceous (?).

Figure 7a,b Vaginulina exilis (Reuss); Sample 261-32, CC; Upper Jurassic-Lower Cretaceous (?).

Figure 8a, b Falsopalmula subparalella (Wisniowskii); Sample 261-322, 59-60 cm; Upper Jurassic-Lower Cretaceous (?).

Figure 9a, b Dentalina communis d'Orbigny; Sample 261-31, CC: Lower Cretaceous (Valanginian).

Figure 10a Nodosaria sceptrum sceptrum (Reuss); Sample 26131. CC: Upper Jurassic-Lower Cretaceous (?).

Figure Ila Nodosaria sceptrum spinicostata Bartenstein; Sample 261-32, CC; Upper Jurassic-Lower Cretaceous (?).

Figure 12a Lingulina nodosaria Reuss; Sample 261-32, CC; Upper Jurassic-Lower Cretaceous (?).

Figure 13a, c Nodosaria zippei Reuss; Sample 261-32, CC; Upper Jurassic-Lower Cretaceous (?).

Figure 14a, c Lagena oxystoma Reuss; Sample 261-31, CC; Lower Cretaceous (Valanginian).

Figure 15a,c Lagena hauteriviana cylindrica Bartenstein and Brand; Sample 261-32, CC; Upper Jurassic-Lower Cretaceous (?).

Figure 16a Nodosaria pseudohispida Gerke; Sample 261-32, CC: Upper Jurassic-Lower Cretaceous (?).

Figure 17a, c Rectoglandulina humilis (Roemer); Sample 261-322, 59-60 cm; Upper Jurassic-Lower Cretaceous (?).

Figures 18a, b; Spirrilina minima Schacko; Sample 261-32, CC; 19a, b Upper Jurassic-Lower Cretaceous (?).

Figure 20a Ramulina spandeli Paalzow; Sample 261-32, CC; Upper Jurassic-Lower Cretaceous (?).

Figure 21a Bojarkaella sp.; Sample 261-32, CC; Upper Jurassic-Lower Cretaceous (?).

Figure 22a, b Nodosaria lagenoides (Wisniowskii); Sample 26132. CC: Upper Jurassic-Lower Cretaceous (?). 
PLATE 2
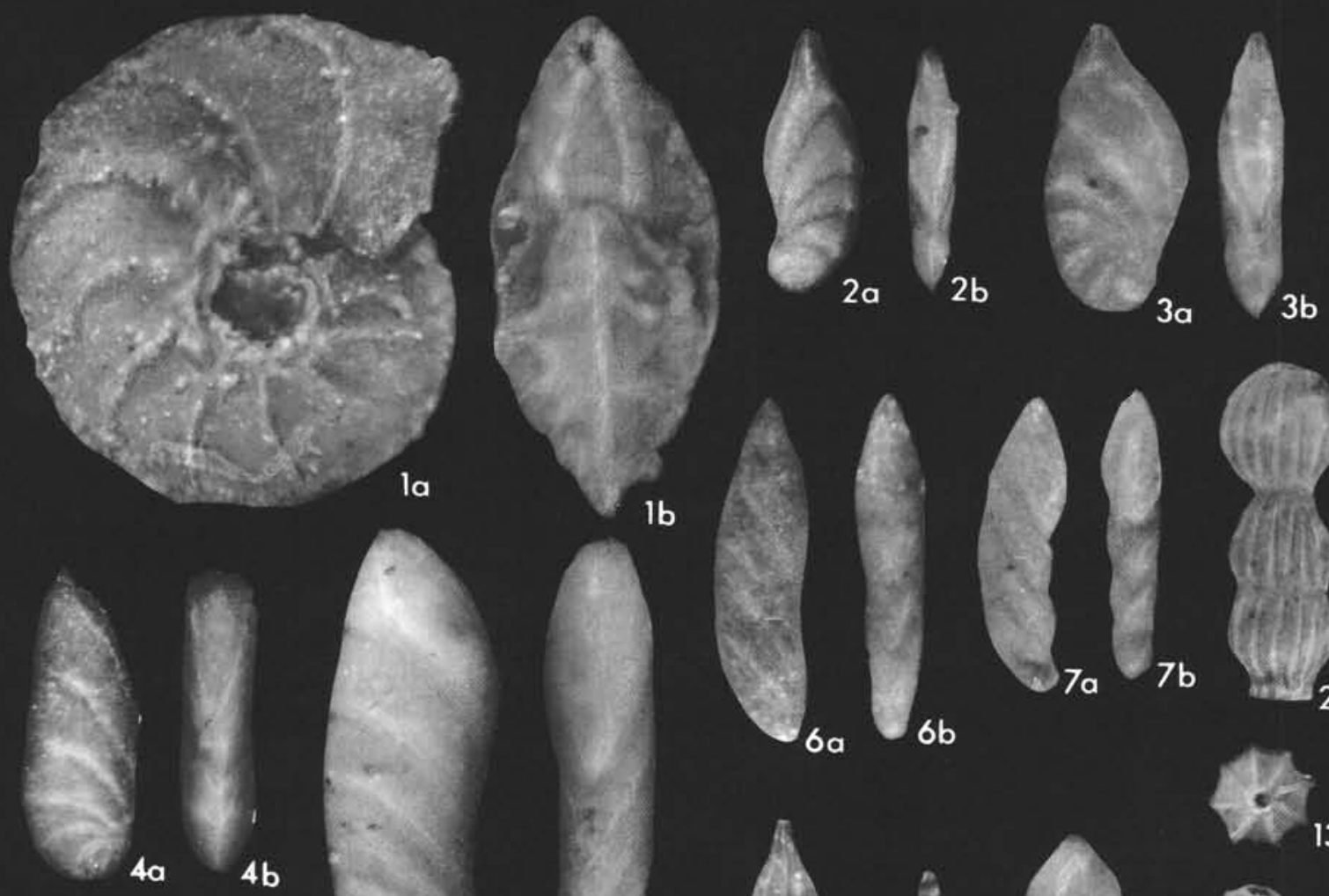

6a
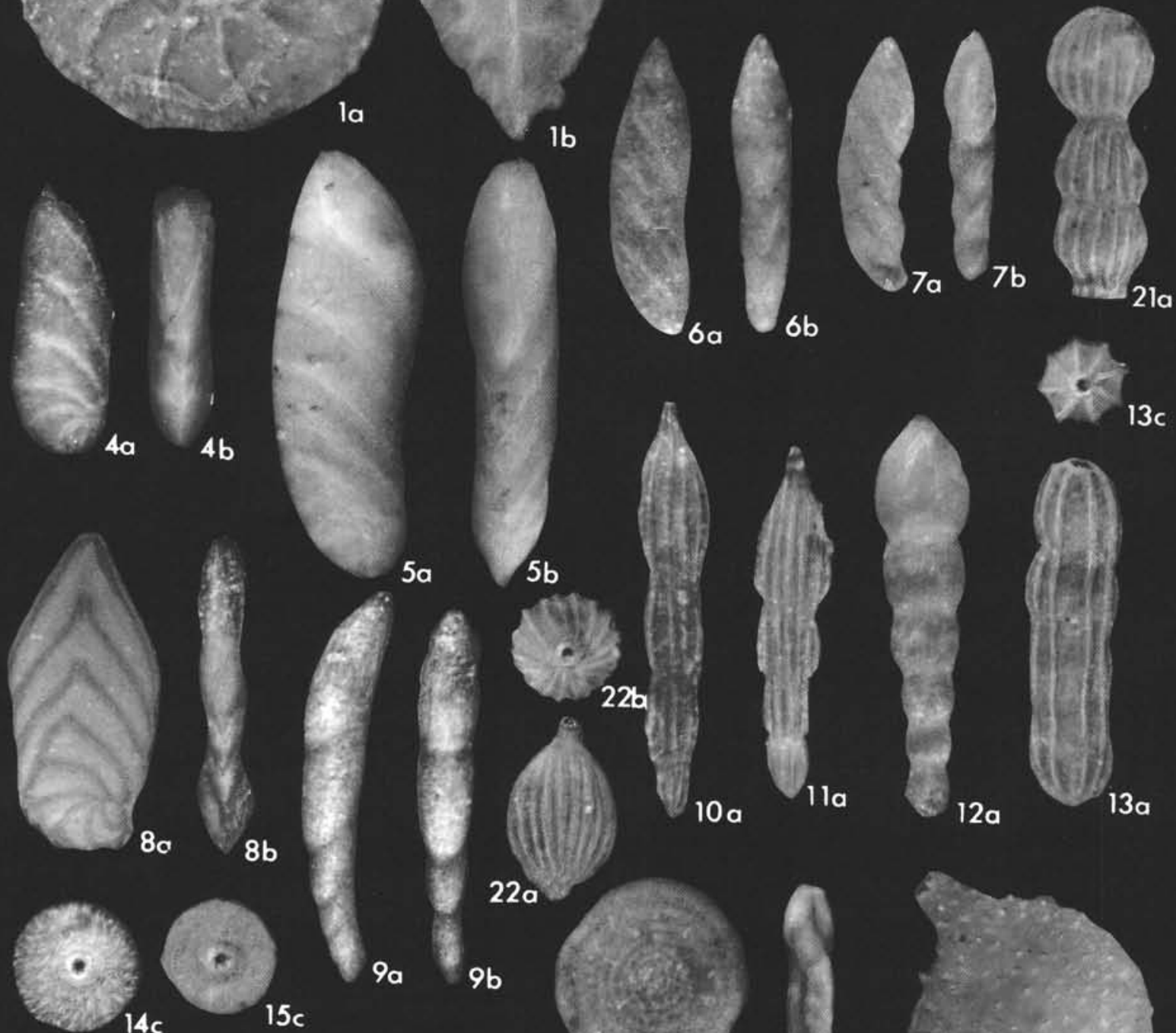

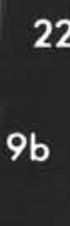

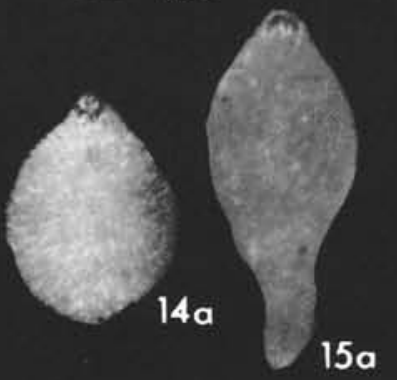
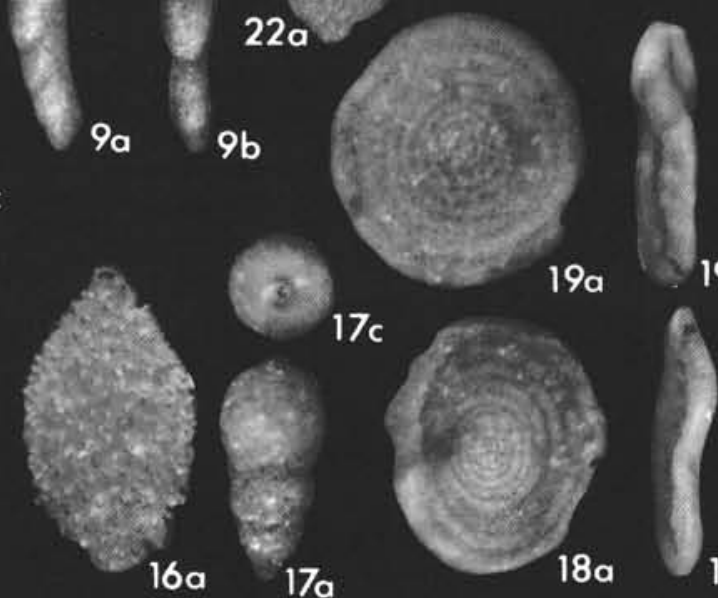

$19 \mathrm{~b}$

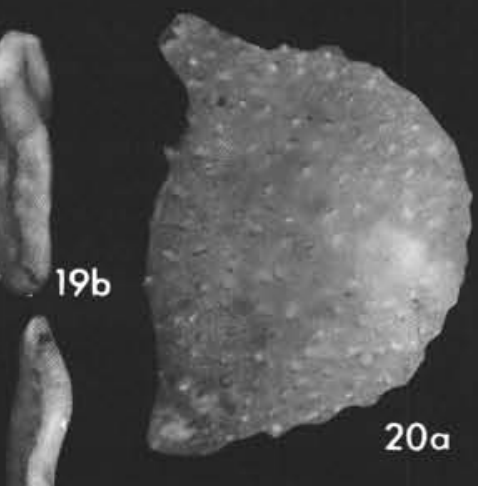

